\title{
Coal Mining in Good Environmental Governance Perspective
}

\author{
Semuel Risal ${ }^{1}$, Abner Herry Bajari $^{2}$, Dorthea Renyaan ${ }^{2}$, Putri Hergianasari ${ }^{3}$, Anak Agung Ayu Dewi \\ Larantika $^{4}$ \\ STIA Bina Banua Banjarmasin, Kalimantan Selatan, Indonesia ${ }^{1}$, Universitas \\ Cenderawasih Jayapura, Papua, Indonesia², Universitas Kristen, Satya Wacana, Jawa \\ Tengah, Indonesia ${ }^{3}$, Universitas Warmadewa, Bali, Indonesia ${ }^{4}$ \\ \{sriza101@yahoo.com\}
}

\begin{abstract}
Coal mining activities in East Kalimantan (Kaltim) have been going on for decades but have not had a significant impact on economic development for the people of Kaltim. This has become a paradox, that Kaltim as the largest contributor to coal nationally continues to experience social, economic, and ecological crises. This study aims to explore coal mining management from the perspective of Good Environmental Governance (GEG) using a qualitative descriptive approach with interactive model data analysis. The data in this study, namely primary data, which was conducted through in-depth interviews and semi-structured data from key sources using the interview guide instrument; and secondary data, in the form of publications and documentation to strengthen the conceptual framework, theoretical analysis, and literature review to support this study. Our analysis shows that coal mining has had a very large impact on ecological damage in Kaltim. Coal mining management based on GEG principles is still jargon because, in practice, GEG principles are still in a vacuum and have not been transformed into a concrete policy in the administration of government in the natural resources sector. So that a natural resource and environmental management policy based on the vision of protection and preservation of environmental functions is needed in supporting the implementation of sustainable development.
\end{abstract}

Keywords: Coal Mining; Ecological Crisis; Environmentalism; GEG; Sustainable Development.

\section{Introduction}

Environmental problems have become complex issues and have begun to receive serious attention from various groups since the 1950 s, ranging from scientists, politicians to the general public. This concern arises in line with the occurrence of various cases of pollution to the environment that claimed many human lives, through various disasters that occurred. Several cases of environmental impacts that caused human casualties, such as in the late 1950s, were the occurrence of pollution in Japan which caused a very terrible disease called Itai-Itai disease. Itai-Itai disease outbreak, which is the most severe stage of chronic cadmium poisoning, has occurred in a valley $3 \mathrm{~km}$ along the Jinzu River contaminated with cadmium (Cd) from the wastes of a Zinc (Zn) mine in Toyama.

In the area, the river was contaminated with slag from upstream of the mine which resulted in the soil in the rice fields being contaminated with heavy metals including cadmium through the irrigation water flow from around 1910 to the 1960s. Meanwhile, residents of the Jinzu River Basin used river water for drinking and cooking their daily needs until around 1960 [1]. 
Then in 1953 the population living around Minamata Bay, Japan experienced an outbreak of neurological disease that ended in death. After conducting research, it was proven that this disease was caused by mercury $(\mathrm{Hg})$ contained in the waste of a chemical factory. The water consumed in the human body has increased levels of the poisoning threshold and resulted in fatalities. The contamination has caused a poisoning disease called Minamata disease.

In 1962 Rachel Carson [2] published a book called The Silent Spring which described a terrible new disease and animal death caused by pollution from the use of pesticides. Several environmental cases that occurred and claimed many lives, caused public concern that prompted environmentalists to hold an environmental conference in the United States in 1968 with the title " The Careless Technology" which stated about environmental damage. caused by foreign aid from developed countries to developing countries which results in environmental disasters. In 1972 an informal organization called The Club of Rome published a work entitled "The Limits to Growth" which predicted that if the trend of world population growth, industrialization, environmental pollution, agricultural production, and resource depletion natural forces continue to occur without making changes, it will be a world catastrophe because the limits of growth on this planet will be reached in the next 100 years.

Humanity's awareness of environmental issues has become increasingly widespread, namely the holding of the United Nations Conference on the human environment in Stockholm, Sweden on June 5-16, 1972. every citizen to formulate it in every environmental management policy. The results of the conference were : (1) Declaration on the Human Environment, consisting of a Preamble and 26 principles in the Stockholm Declaration ; (2) Action Plan for the Human Environment (Action Plan) consisting of 109 recommendations. Declarations and recommendations from this conference can be grouped into five main areas, namely settlements, natural resource management, pollution, education, and development. The Stockholm Declaration also calls for the nations of the world to have an agreement to protect the sustainability and improve the quality of the environment for human life. So that environmental issues become an important part of sustainable development.

The sustainable development paradigm adopted by most of the world's countries has begun to raise various future challenges. The problem of environmental damage and cases of pollution that hit all countries in the world are considered as the impact of industrialization development and excessive exploitation of natural resources. This situation is then considered to threaten the sustainability of future life. In response to this problem, the United Nations then formed the World Commission Environment and Development (WCED) to study these problems related to the environment and development. The results of this research and study were stated in a report entitled our common future in 1987 which gave rise to the concept of sustainable development $[3]$.

However, the sustainable development paradigm has not been able to suppress the exploitation of natural resources, although the basic concept is to carry out development to meet current needs without compromising the needs of future generations by focusing on environmental carrying capacity, achieving social justice, economic and environmental sustainability. However, until now exploitation SDA continues to spread through the extractive industries which further adds to the complexity of the problems associated with damage to the ecology [4]; [5].

The province of East Kalimantan, which is abbreviated as Kaltim, has a population of 3.77 million people [6]. East Kalimantan has two seasons, namely the dry season which usually occurs from May to October, and the rainy season from November to April. Has as many as 157 rivers large and small. There are 18 lakes with the 3 largest lakes, namely Lake Melintang covering an area of 11,000 ha, Lake Semayang covering an area of 13,000 ha, and Lake Jempang 
covering an area of 15,000 ha. Meanwhile, the number of the total critical land area of about $7,739,428.28$ ha $(62.34 \%$ of the total area of East Kalimantan), while the area of critical land in the forest area of about 5,413,215.49 ha, or $66.34 \%$ of the total forest area in the province of East Kalimantan is around 8,159,458.10 ha [7].

In 2012, the forest area of East Kalimantan was around 14,981,978 hectares (ha), and within 8 years, namely in 2020, the forests of East Kalimantan experienced a very drastic decline to $8,434,906$ ha. Of this amount, within 8 years, East Kalimantan has lost an average of 818,384 ha of forest area per year or an average of 2,273 ha per day. So that the crisis on the island of Kalimantan is very real, especially in the province of East Kalimantan. The area of forest management, large-scale oil palm plantations, and mining reaches 21.7 million ha. Currently, there are 33 Coal Mining Concession Work Agreements (PKP2B) and 1,212 Mining Authorizations (KP) issued by the government. To meet the demand for coal in the international market, the East Kalimantan provincial government abandoned the plan to reserve 2.49 million ha of agricultural land for food crops and horticulture (Provincial RPJPPD 2005-2025). Even 3.12 million ha of land is designated and converted into mining concessions [8].

Samarinda City as the capital of East Kalimantan Province is known as a mining city because more than half of Samarinda's city area is surrounded by 81 coal mining permits. The coal mining permit in Samarinda was first started in 2001 with an area of 87.52 ha. Then up in 2005, there were 38 permits with an area of 20,323, 1 ha, and in 2009 there were 76 IUPs with an area of 27,555.66 ha. Mining Advocacy Network (Jatam), states that 76 Mining Business License (IUP) issued by the City Government of Samarinda and 5 PKP2B permits issued by the government, which is widely concession spend 71 percent of the city of Samarinda. The mining area is 38,814 ha or more than half of the 71,823-ha area of the city of Samarinda.

Mining activities make a major contribution to the national economy, including providing employment. However, on a micro-scale, environmental degradation is more prominent with the environmental impacts it causes, which then has an impact on the process of marginalizing local communities, especially for those who depend on the agricultural sector for their lives. Environmental degradation causes agricultural land to become infertile, while farmers' access to fertile land and other economic resources is limited. This condition is exacerbated by the emergence of various ecological disasters that hit East Kalimantan. Even in the vicinity of the coal dredging area, the quality of life of the residents has declined. Kaltim Post reported that gonorrhea sufferers are increasing in the productive age group, 20-40 years. Even sufferers of Acute Respiratory Infection (ARI) due to environmental disasters such as mine dust and smog in East Kalimantan reached 39,804 people by 2015. This gloomy generation portrait indicates the absence of management and administration of areas that ensure the safety of local communities.

Fenomena that occur because of the political environment that is played through the government-issued policies ranging from the local to the national level is more oriented to economic interests alone. East Kalimantan is the richest province in Indonesia, which is characterized by a natural resource-based economy. This can be seen from the country's per capita Gross Regional Product (GRP). East Kalimantan is blessed with various natural resources, such as oil, gas, and mining, especially coal, timber, and other forest products. East Kalimantan is also one of 4 provinces rich in natural resources (Riau, Aceh, and Papua Provinces) which are above the national average in DRR both per capita income and growth rate (Hill, 2011 and Sjoholm, 2012). Moreover, the industry in terms of the share of the manufacturing sector in the PRB, compared with three other resource-rich regions in Indonesia (Riau, Aceh, and Papua). 
Despite the ongoing development potential, the cases mentioned above show serious problems related to the destruction of the ecological order. So at this locus, natural resources turned into an ecological disaster for the modernity of human life. So, we need a paradigm that departs from the perspective of management GEG coal mining based on the principles that should be transformed into a concrete policy in governance in the natural resources sector. So that natural resource and environmental management policies must be based on the vision of protecting and preserving environmental functions in supporting sustainable development as an alternative paradigm in natural resource management in East Kalimantan.

\section{Literature Review}

\subsection{Good governance}

The concept of governance began to develop in the early 1990s and was developed as a form of disappointment with the concept of government where the government is considered to have enormous power so that people do not have room to develop. The government is considered to have become the institution that knows best and understands what the people want so that many policies are made without involving the participation and aspirations of the community. As a result, the policy becomes top-down. This situation then made the public to be skeptical of the government [9].

Under these conditions, a new view of government has developed, about what the government should do, and how the government is responsible. This gave birth to a new concept known as governance. The affirmation of the elements of governance that must move in synergy as conveyed by Taschereau and Campos [10] that three important elements will influence each other and form an inseparable unit (interlock), namely the state, the private sector, and civil society. Optimism about this idea naturally arises because state management is driven by the synergy of the three great powers. While UNDP (1997) defines governance as: "the exercise of administrative, political and economic authority to manage the problems of a country at all levels which includes mechanisms, processes, and institutions when citizens and community groups express interests, exercise political rights, fulfill obligations, and discuss the differences between them" [11].

Bevir [12] through a conclusive statement in his article said that "Governance -whether it is taken to be a new phenomenon or ubiquitous-refer to a pattern of public administration through the network". Thus, it is clear that the network of cooperation is the main strength of governance itself. So that governance no longer refers exclusively to the government, but also refers to the use of power in institutions or organizations outside the government. That the government/state is no longer the sole agent in governance. Building a wide network with various elements and other institutions is a necessity and a must so that the state has additional energy in realizing the goals of the state and the expectations of its public.

Therefore, understanding governance is understanding how to integrate the roles between the government (bureaucracy), the private sector, and civil society in a mutually agreed rule of the game. This is in line with the definition of the State Administration Agency (LAN) which states that good governance is an effective and efficient, solid, and responsible government administration by maintaining a synergistic interaction between state domains including the government, the private sector, and the community.

In the practice of governance, the role of the community is as important and equal to the role of the government and the private sector. The community can facilitate socio-political interaction and mobilize various groups in society to be involved in social, economic, and 
political activities. Organizations civil society can channel people's participation in social and economic activities and organize into a group with more potential to influence public policy in achieving common prosperity.

Good governance is an effort to change the character of the government from working alone, to be more concerned with community involvement and aspirations. In good governance, society is no longer seen as an object but as a subject who also works in development programs. Thus, a democratic system of government is a prerequisite for the implementation of good governance to ensure the distribution of social justice and welfare for the entire community.

\subsection{Good Environmental Governance and Sustainable Development}

The paradigm of sustainable development adopted by most of the world's countries began to raise various future challenges. The problem of environmental damage and cases of pollution that hit all countries in the world are considered as the impact of industrialization development and excessive exploitation of natural resources.

This situation is then considered to threaten the sustainability of future life. In response to this problem, the United Nations then formed the World Commission Environment and Development(WCED) to study these problems related to the environment and development. The results of this research and study were stated in a report entitled our common future in 1987 which gave rise to the concept of sustainable development [3].

According to WCED, sustainable development is defined as development that seeks to meet the needs of the present without compromising the ability of future generations to meet their own needs. The concept of sustainable development contains two important ideas, namely:

a. The idea of "needs", in particular, the essential needs of the world's poor, which should be prioritized;

b. The idea of limitations stemming from the state of technology and social organization on the ability of the environment to meet current and future needs.

In the sectoral book Agenda 21 Book 1: Guidebook for Sustainable Development: An Effort to Achieve A Better Quality of Life (2000) it is stated that: “...unlike other existing development theories brought up by economic development thinkers,...the emergence of sustainable development concept has a different dimension. The emergence was closely connected with the rise of the environmental awareness"

The above statement shows that sustainable development is very closely related to environmental awareness. The environmental crisis caused by the exploitation of natural resources for the needs of economic development is something that must be considered in the concept of development.

Based on the results of the Earth Summit in Rio de Janeiro, 1992, the essence of sustainable development includes three aspects, namely; ecology, economy, and social security, hereinafter referred to as the triangle of sustainability. Development is said to be unsustainable if development is only centered on social and economic aspects but must pay attention to the availability of natural resources for the long-term needs of future generations.

Departing from this awareness and the rise of environmental discourse in various international conferences, the principles of good governance as good governance, in the management of government administration, must integrate the principles of sustainable development which include ecological, economic, and socio-cultural aspects. To realize attention to the environmental crisis in governance, the term known as good environmental governance was born. In good environmental governance, there are three main 
principles, namely; 1) make decisions at the right level; 2) providing access to information, participation, and compensation, and 3) integrating environmental aspects in all policies.

Initially, the application of the concept of good governance was only based on observations or theorizing about social interaction and governance. However, it has not studied in depth the dynamics of the ecosystem. Ecosystem dynamics are explained in depth in the concept of environmental management based on the interaction of biophysical systems. Through the idea of good environmental governance, it is hoped that reforms in the implementation of good public interest can be formulated by referring to and prioritizing ecological values. More specifically, good and bad governance is not only seen from the quality of the relationship between the state and its people, but also from its commitment to upholding ecological principles [9].

Thus, the meaning of good governance is still technocentric and does not guarantee environmental sustainability. For this reason, it is necessary to integrate the concept of environmental management into the principles of good governance, by the formulation of sustainable development. The relevance of the concept of good environmental governance is in the effort to understand and manage the interrelationships between social systems and ecosystems.

Moreover, the management of the social system needs to be managed by prioritizing ecological values and vice versa, the resilience of the ecosystem can be maintained through the management of the social system that is guided by ecological principles. The concept of good environmental governance needs to be built on the central premise that social systems and ecosystems, over time, engage in continuous interactions. So basically, the concept of environmental governance wants to direct our perspective to see all problems from an environmental point of view. The environment is a major consideration in every decision taken.

\section{Research Method}

This study uses a content analysis approach, which is a research approach that focuses on an in-depth investigation of an object. Data was collected using the purposive sampling technique with a focus on the exploitation of natural resources that have implications for ecological damage. The data in this study, namely primary data, obtained through in-depth and semi-structured interviews from key informants; and secondary data, in the form of publications and documentation to strengthen the conceptual framework, theoretical analysis, and literature review to support this study related to natural resource management, especially coal mining in East Kalimantan by conducting interviews with policymakers, entrepreneurs and communities who have experienced the impact of ecological damage in East Kalimantan.

Interviews were conducted to reveal the attitudes and perspectives of the informants to obtain important information about events or realities related to natural resource management. Next, explore the management of coal mining in the perspective of Good Environmental Governance (GEG) using a qualitative descriptive approach with interactive model data analysis.

It should be noted that within the context of contemporary social science, the text reflects a methodological strategy, so we detailed the questions through an interview guide, from which data were collected and interpreted. To explore the issues outlined above, the first part of this article contextualizes coal mining management based on GEG principles. Then, the methodological design of the investigation is detailed, which opens up space for debate about 
the dimensions explored during the interviews, highlighting the option of dealing with each empirical dimension with the relevant literature, to avoid the prior general review of references.

The last part of this paper reflects on the phenomena and perspectives echoed in the previous section, draws on the research findings, and reflects on the exploitation of natural resources with impacts on ecological damage. The data obtained were analyzed using an interactive analysis model consisting of four stages, namely data collection, data reduction, data presentation, and concluding.

\section{Results and Discussion}

In general, the island of Kalimantan has coal reserves of 51.9 billion tons, or $49.6 \%$ of Indonesia's coal reserves. East Kalimantan province has coal reserves of 37.5 billion tons or $35.7 \%$ of the national coal reserves and is the most active and progressive province in coal mining compared to other provinces. Currently, East Kalimantan dominates coal mining business permits on the island of Kalimantan as many as 1,476 units with an area of 5,406,566 ha (Distamben Kaltim, 2017 ). The existence of coal mines has contributed significantly to the East Kalimantan economy, which is $50 \%$ of the Gross Regional Domestic Product (GDP), but more than $6 \%$ of the population is still below the poverty line [13].

So far, the dominant paradigms in the management of natural resources are developmentalism and neoliberalism which are very economic-centric. Given the two paradigms, natural resources are treated as consumptive objects in achieving the ratio of economic growth and development. This is what then gives rise to excessive exploitative behavior in dredging up the earth's wealth and exploiting it as much as possible for economic purposes. The implications that arise later are the socio-economic crisis and the destruction of the natural environment ecosystem structure which is followed by the presence of natural disasters as a form of "anger" of nature to greedy humans. So at this locus, East Kalimantan Province, which has a large natural resource wealth, has turned into an economic curse for the modernity of human life, which excludes justice for the community [4].

Countries with large natural resources (SDA) should have relatively better economic performance than countries with limited natural resources. However, Indonesia, which has abundant natural resources, has not been fully utilized for the prosperity of the people, but its natural resources have been exploited for the benefit of advanced industrial countries and national and international capital powers. The exploitation of forests, especially coal mining, land grabbing, and other natural resources has caused damage to water, soil, and air resulting in ecological disasters and the displacement of people from their sources of life. The state as the ruler of natural resources has not been able to distribute the results of its natural resources for the benefit and benefit of the people. The concept of a state that functions as a regulator and servant of its people, in fact only serves the interests of the power elite and investors.

The state and corporations have a large portion in managing natural resources as capital producers. The state is given a role as a regulator and corporations as executors in the field. The emergence of these two hegemonic actors in the management of natural resources management has implications for the marginalization of the community as legitimate actors in the management of natural resources in their area. Local communities are not given a role in the management of natural resources which are their customary rights. The state and corporations appear as double predatory actors in seizing the community's natural resources in the name of development.

After the practice of exploration and exploitation is completed and natural resources have been looted, what remains is the destruction of nature and the ravaged community environment. 
This is where the natural resources wealth around the local community turns into a curse and disaster because the local community automatically loses their source of income. The development generated from natural resources itself is not enjoyed by local people, because the results of the wealth of their natural resources are transferred to the city as an economic center. So, what happened next was the creation of a widening gap in inequality accompanied by many cases of poverty, hunger, declining public health sanitation, and ecological damage.

This exploitative political economy policy in which there has been a very glaring inequality in the control of natural resources has caused ecological destruction in almost every inch of land in Indonesia. Ecological destruction is getting bigger due to the alliance of the power elite of the country with the power of capital. Meanwhile, the risk of environmental damage and loss of assets for survival is borne by the people. The power elite and the owners of capital have a close relationship with the socio-economic crisis and the destruction of the ecological system. The ecological crisis occurs because the state, investors, and modern knowledge systems have reduced nature to a pile of commodities that can be engineered and exploited to obtain shortterm economic benefits so that in turn various environmental disasters such as floods, droughts, pollution, and water crises have become disasters suffered people from year to year [14].

Deteriorating environmental conditions and current environmental policies greatly affect the right to life, the right to health, the right to work and education, as well as other human rights. Ecological losses occur as a result of mining activities that damage the environment, privatization of water resources, destructive logging, and illegal fishing practices and damage the environment. Indonesia's abundant natural resources have included this country in the list of sources of dredging and targets of colonization by international capital. Apart from taking advantage of the export of raw materials at low prices, they also used this opportunity to ensure the repayment of government debts.

The legal basis for managing Indonesia's natural resources before the decentralization and regional autonomy policies, especially in the mineral and coal sector, is Law no. 11/1967 which regulates the first generation of work contracts in the management of mineral and coal resources. The spirit in the contract of work as domestic legality of the management of natural resources is a relationship of lex specialist (a special legal relationship) between the owners of capital and the state, as the property owner SDA legitimacy according to Act 1945 Section 33. In politics, this is where the beginning of dependence is created, in where spirit capitalists are very dominant in determining the characteristics and modes of natural resource management.

A systematic effort to combine economic power, socio-political power, and the military, so that the life of the nation is under the power of the owners of strong capital [5]. The combination of economic and political power has a major impact on people's lives. This kind of concern, as well as systematic and continuous efforts to integrate the state into the capitalist system, make people even more oppressed and exploited by various policies issued by the government [15].

In the late $1980 \mathrm{~s}$, empirical studies began to emerge showing that natural resources that should be a blessing to the country/region that owns them, can weaken the economy. The negative relationship between the abundance of natural resources and economic growth, which in the terminology of [16] is known as the "natural resource curse". Studies on the idea of the "natural resource curse" were introduced by several political-economic scientists, among them are [17]; [18]. Their locus of study focuses on the paradoxical phenomenon that occurs in the case of countries rich in natural resources, but instead of being rich, they become poor and are hit by social conflicts, causing inequality between the state and society.

The essence of natural resource wealth as an economic commodity is the basic factor of producing capital as the basis of a country's economic activity so that special handling is needed and requires monopoly power to extract natural resources in the form of income so that in this 
case ownership of high capital and technology power becomes the highest priority in natural resource management [19].

Siti Maimunah [8] said that the change in state administration power towards decentralization and regional autonomy did not reduce the degree of the misery of local communities in East Kalimantan. Since the era of Soeharto's leadership until SBY, East Kalimantan's role has been to become an independent cash register in the name of development and acceleration of economic growth through the exploitation of natural resources. In the era of the 1980s, Kalimantan became Indonesia's largest supplier of timber exports.

In the millennium era, deforestation decreased, then shifted to the highest capacity coal mining, which produces more than 200 million tons per year. Like several provinces on the islands of Sumatra and Papua which have large natural resources, the province of East Kalimantan is experiencing an extraordinary paradox. Despite having abundant natural resources, Kalimantan is synonymous with poverty and marginalization of local indigenous people (Dayak indigenous people) because their population continues to shrink.

Meanwhile, Walhi Kaltim revealed that the problem of deforestation was getting worse. Hundreds of coal mining companies in East Kalimantan are now borrowing and using forest areas, threatening its sustainability. Unfortunately, some of the lands that are used as a borrowto-use area by the coal mining company are included in the protected forest category. Morally and for the sake of saving the remaining natural forests of East Kalimantan, no argument justifies when the new Minister of Forestry approved the loan of forest areas for activities outside of forestry proposed by the district/city government and more than 60 mining companies in East Kalimantan.

The Director of Walhi Kaltim revealed that in the process, the central government through the Ministry of Forestry should not grant a permit for borrow-to-use forest areas for activities outside of forestry, even though the rules/regulations are justified when there is a Decree from the Minister of Forestry regarding the borrow-to-use area of forest. This application must be studied in depth considering the increasing rate of deforestation in East Kalimantan and even reaching into protected forests [14].

Furthermore, Walhi Kaltim noted that since 2001 the deforestation rate in East Kalimantan has reached 350 thousand ha every year, causing losses to local communities who still depend on forest products for their livelihoods. The data obtained by Walhi revealed that the most areas applying for borrow-to-use forest permits were in South Kalimantan with 72 coal companies, then in East Kalimantan with 65 companies, Central Kalimantan with 20 companies, and West Kalimantan with 8 companies.

The exploitation of forest areas in East Kalimantan has a very significant impact on the sustainability and sustainability of forests in East Kalimantan and indirectly affects ecological disasters. And it cannot be denied that the exploitation of coal mining is the largest contributor to deforestation of forest areas in East Kalimantan and until now the reclamation carried out by several large coal mining companies in East Kalimantan has not been running optimally. The weak realization of the reclamation program was proven by the discovery of several lands that had not been reclaimed optimally by a team from the Provincial DPRD in 2014 [14].

This is in contrast to the green East Kalimantan (go green) which was launched by the East Kalimantan Provincial Government through the OMFIT (one man five trees) program which was declared at the Kaltim Summit on January 7, 2010. The area of critical land in East Kalimantan is increasing every year. In the year 2014 Data BPDAS and BPKH mention critical land in East Kalimantan reached 6,402,472 ha and in year 2017 has reached 11,508,722 h a . $\mathrm{P}$ there is year 2018 of the critical land area of 5,762,225 ha targeted in year 2023 fell to 
$3,402,536$ ha through rehabilitation and reforestation activities and programs of "one man five trees" as much as 7,628,145 trees.

As a form of realization of one man five trees, up to 201 November, 6 government and society Kaltim has successfully planted trees as much as $28,155,547$, but the tree planting program remains an issue and the debate on the effectiveness and success rate. You can imagine how fast a tree grows, let alone a tree planted on nutrient-poor soil compared to the rate of deforestation of forests and land which, when compared to the Ministry of Forestry data, reaches a ratio of 1 minute, Indonesia loses forest the size of a football field. With an average increase in critical land of 1,017,650 ha/year, it is almost impossible for the " one man five trees" program to answer the rate of deforestation. In reality, East Kalimantan is not getting greener but on the contrary, East Kalimantan is heading towards ecological gloom.

The number of mining business permits issued by the East Kalimantan PAD government has increased significantly. East Kalimantan Province's GRDP according to business fields based on current prices in 2008 and is the province with the highest level of GRDP in Indonesia which reached Rp. 314.9 trillion, although in 2009 it fell to Rp. 285.6 trillion, in 2010 rose again to Rp. 321.8 trillion, in 2011 Rp. 391.8 trillion, in 2012 Rp. 419.5 trillion to reach Rp. 425.5 trillion, in 2013 with a percentage of GRDP sources from the mining and quarrying sector of $42.91 \%$ (BPS Kaltim, 2013). And the most crucial thing is, with 71 percent of the area under IUP siege, coal mining and making a significant contribution to East Kalimantan even to the state but the distribution of benefits from natural resources wealth is not enjoyed by the general public in East Kalimantan.

The province of East Kalimantan, which is one of the largest provinces in Indonesia, is not even able to meet the independent food needs of its population which is growing at 3.7 percent per year. Referring to Kaltim in figure data [6], rice production in East Kalimantan in 2018 was 262,773 tons, and in 2019 it fell to 253,818 tons. Not only rice, but rice production has also decreased from 152,059 tons in 2018 to 146,887 tons in 2019 and is not sufficient for the needs of the East Kalimantan population, so that every year East Kalimantan brings hundreds of tons of rice from South Sulawesi, Java, and South Kalimantan. About 83 percent of protein needs also come from outside the region. It is not enough to sacrifice food security; East Kalimantan continues to experience an electricity crisis amid an abundance of coal. Since the extractive industry has become the driving force of the economy, East Kalimantan's food and energy security has been in shambles. It is not prosperity and welfare enjoyed by the community, it is the curse of natural resources and ongoing suffering that leads to social, economic, and ecological crises [8].

Until September 2020, the number of people living below the poverty line was around 243.99 thousand, or about 6.64 percent of the total population. This number increased compared to March 2020 of 230.26 thousand or around 6.10 percent, meaning that the number of poor people in absolute terms increased by 13.73 thousand people and increased by 0.54 percent in percentage [6]. The pockets of unemployment are concentrated in the city of Samarinda and Kutai Kertanegara Regency which have the highest number of mining concessions (KP) in East Kalimantan. In Kutai Timur district, where the economy depends on coal, 48 percent of the population is classified as poor. Ironically, about 45 percent of the poor live scattered around the coal mining area.

Developing countries are currently increasingly aggressively exploiting the wealth of natural resources, to catch up with developed countries. Modernization is narrowly interpreted as development where the benchmark is solely on economic growth. Likewise with the effects of globalization gave birth to a free market where many trade regulations were applied which 
killed the industry in developing countries and made it more profitable for multinational companies from developed countries to invest in developing countries.

Vandana Shiva [20] assessed that the dimension of developmentalism that took place in third world countries itself was a continuation of colonialism practices that occurred in the past. Shiva proposed the term "exploitation syndrome" to criticize the discourse of developmentalism that developed in third-world countries. The syndrome includes two main stages.

First, the emergence of private ownership of goods to replace public goods in natural resource management. The concept of public ownership itself is considered unprofitable from an economic point of view and does not encourage people to express themselves freely in economic activities. Ownership of private goods creates a large consumptive behavior to satisfy their respective economic needs, thus creating the phenomenon of the tragedy of the commons in society. The tragedy of the Commons is a term popularized by Garrett Hardin [21] regarding the imbalance between the consumptive needs of the human population and the availability of natural resources in the environment.

The existence of this imbalance creates human greedy behavior to continue to meet their needs by continuously exploiting natural resources. Nature, which was originally collective goods, was later divided into private ownership of goods as a form of action of economic rationality. As long as these natural resources still provide abundant natural wealth, humans will be encouraged to exploit them until they run out. Until one day when these natural resources run out, humans will move to look for other potential natural resources to be exploited.

Second, the establishment of a government bureaucratic apparatus that legalizes and permits the commercialization of these public goods because state revenues are highly dependent on the extraction industry produced from these natural resources. The transition of natural resources from public goods to private goods is closely related to global disorders and global instability which emphasizes de-stateization in the economic aspect [22]. The excessive role of the state in regulating economic activity is considered uncompetitive in building and creating a healthy economic climate to create economic growth rates [23]. The market should be encouraged as an executor in creating economic growth. The first step is to commodify noncommercial economic resources controlled by the basis of communal ownership by local communities. This commodification creates marketable goods conditions, namely a situation where public goods that are actually of social value turn into private goods of economic value.

In the perspective of Ecology-Political which was introduced by Ulrich Beck [24] through his idea about the Risk Society. In the view of modernism, the risk community itself is present in the form of the birth of human awareness about disasters that will occur in the future. Modern humans think that the presence of disasters in the future itself can be minimized and its destructive risks to modern human life can be reduced. The presence of a disaster is something fatal in the linearity pattern of the development of human life as is the paradigm of modernism because disaster will destroy the achievements of human development so far in an instant.

This conception of the risk society encourages humans to be friendly with the natural environment so that disasters caused by natural damage are more manageable for their risk impacts. So, at this level, the environment has a place as a participant subject in better natural resource management. Modernity has also begun to embrace the forms of norms, values, and knowledge in the local wisdom of the community to reformulate natural resource management. So that the ecological-political perspective is present as an alternative paradigm in formulating affirmative resource management with the conditions of the natural environment.

Therefore, this study of political ecology always criticizes and questions the concept of political economy in developmentalism which plays a major role in environmental change. Both nature and humans have been in a binary opposition relationship were humans, who are 
considered to be the regulators of natural resources on this planet, always act arbitrarily to the environment so that it becomes damaged. The ecological-political perspective rejects the flow of anthropocentrism that develops in the discourse of developmentalism. Nature is only likened to a non-living entity that is only an object of power for humans. In this case, the perspective of political ecology itself encourages ecocentrism. The ecocentrism paradigm is a flow in environmental ethics that positions humans and nature in a reciprocal relationship and needs each other as part of the biosphere community.

Shiva criticized that so far the rules for managing resources are not clear and only take place on a top-down basis so that the community only accepts its implementation, cannot protest against these rules which ultimately harm the community as well. Therefore, the management of natural resource management must also provide affirmative action for the community to appear as an important actor in addition to the state and society. According to Shiva, nature has been treated like a cash cow that is forced to continuously meet human needs without any human reciprocity to renew the natural condition. In this case, Shiva called for justice for the environment (environmental justice). Nature needs to get justice in the form of legal legality and political products that need to be fought for. The dimension of justice for the environment includes various aspects, namely the involvement of local knowledge, advocacy for environmental destruction, as well as encouraging the creation of an international environmental conservation panel.

The first thing that needs to be realized in restructuring natural resource governance to be more environmentally friendly is to instill a green thought spirit. This spirit invites all elements of society to rethink the meaning of nature as a form of a living creature. In this case, green thought seeks to deconstruct the dichotomy of valuable (valuable) and non-valuable (nonvaluable) in valuing and treating natural resources. Natural resources that are considered valuable such as mines and minerals will be treated specially because they can produce prosperity for humans while those that are not valuable will only be left by humans.

The second is to put the essence of environmentalism in the formulation of public policies, especially those related to development. Environmentalism is defined as a political attitude that puts forward environmental issues as a form of agenda that is fought for in gaining power. In this case, the attitude of Environmentalism can be seen from the formation of green parties in European countries where the parties prioritize environmental problems that are damaged due to industrialization patterns that produce substances that are harmful to natural ecosystems. So far, the main paradigm that has developed in the formulation of development public policies has always emphasized the economic-oriented aspect.

In Indonesia itself, efforts to realize Good Environmental Government-based natural resource management have faced various challenges, both from the elements of government administration, formal legal, and politics. First, the government, in the process of formulating policies that have been contained in the set agenda, the environment has always been secondary and prioritized aspects of environmental benefits. The AMDAL (Environmental Impact Analysis) document is only considered as a portfolio of policy archives without any follow-up from the government. In addition, in terms of legal legality in the protection of the environment and natural resources in Indonesia in the form of environmental law, it can be said to be very minimal.

Second, formal law, the lack of application of environmental law as the legal basis for environmental policy. Environmental Law itself is a legal approach that is oriented towards the protection of the environment. The environment itself in a legal perspective is then translated as the complexity of the reciprocal correlation of human and natural dependence. 
Third, in the political context, in Indonesia itself, no party fully fights for environmental sustainability as its political agenda in the form of the formation of a green party. The lack of political attention to environmental sustainability will certainly hinder the realization of a more just natural resource management pattern for nature. So far, political parties in Indonesia have been dominated by pragmatic rather than idealistic agendas as a benchmark for the struggle of political parties. This is what causes political parties to only think about the dimensions of power without any political interests being fought for. Therefore, the ideological context in the face of political parties in Indonesia is practically non-existent. The existence of this political reality causes political ecology to be less accepted as the ideological basis of political parties in Indonesia.

\section{Conclusion}

Good governance is the initial concept of good environmental governance as a paradigm for environmental protection and management. That the principle of good environmental governance in the management and protection of the environment is oriented towards good governance. However, in its implementation in East Kalimantan, the synergy between the government, the private sector, and the community has not been well developed to manage and protect the environment. The main paradigm that develops in policy formulation always emphasizes an economic orientation.

So that natural resources, especially coal mining, become piles of commodities that continue to be exploited and have a huge ecological damage impact in East Kalimantan. The rate of deforestation in East Kalimantan continues to increase so that forest degradation is around $30 \%$ and $84 \%$ of the total degradation in East Kalimantan. Coal mining management based on GEG principles is still jargon because, in practice, GEG principles are still in a vacuum and have not been transformed into a concrete policy in the administration of government in the natural resources sector.

Therefore, it is necessary to have a policy for managing natural resources and the environment based on the vision of protecting and preserving environmental functions in supporting sustainable development.

Acknowledgments

We would like to thank all research participants for giving their time and sharing their perspectives for informing this paper. Every mistake is our responsibility.

\section{References}

[1] Aoshima, K., "Itai-itai disease: Lessons from the investigations of environmental epidemiology conducted in the 1970's, with special reference to the studies of the Toyama Institute of Health]," Nihon Eiseigaku Zasshi., vol. 72, no. 3, pp. 149-158, 2017, doi: 10.1265/JJH.72.149.

[2] R. Carson, Silent Spring . 1962.

[3] United Nations, "Report of the World Commission on Environment and Development," 1987. Accessed: Sep. 14, 2021. [Online]. Available: https://sswm.info/sites/default/files/reference_attachments/UN WCED 1987 Brundtland Report.pdf.

[4] S. Risal, D. Paranoan, and S. Djaja, "Analisis Dampak Kebijakan Pertambangan Terhadap Kehidupan Sosial Ekonomi Masyarakat Di Kelurahan Makroman,” eJournal Adm. Reform, 
vol. 1, no. 3, pp. 516-530, 2017.

[5] S. Risal, S. Zauhar, S. Sarwono, and H. Hermawan, "Impact of Decentralization in East Kalimantan Province on Mineral and Coal Mining Policy," J. Public Adm. Stud., vol. 005, no. 01, 2020, doi: 10.21776/ub.jpas.2020.005.01.6.

[6] BPS, Kalimantan Timur in Figures 2020. BPS-Statistics Central Agency of East Kalimantan Province, 2020.

[7] K. Mackinnon, Ekologi Kalimantan Buku III seri Ekologi Indonesia. Jakarta: Prenhallindo, 2000.

[8] S. Maimunah, Negara tambang dan masyarakat adat : perspektif HAM dalam pengelolaan pertambangan yang berbasis lingkungan \& kearifan lokal. Malang: Intrans Publishing, 2012.

[9] L. Budiati, Good governance dalam pengelolaan lingkungan hidup. Ghalia Indonesia, 2002.

[10] S. Taschereau and J. E. L. Campos, Governance innovations : lessons from experience: building government-citizen-business partnerships. 1997.

[11]A. Dwiyanto, Reformasi Tata Pemerintahan dan Otonomi Daerah. Yogyakarta: Pusat Studi Kependudukan dan Kebijakan, Universitas Gadjah Mada, 2003.

[12] M. Bevir, "Interpreting British Governance," Br. J. Polit. Int. Relations, vol. 6, pp. 130136, 2004, Accessed: Sep. 14, 2021. [Online]. Available: https://escholarship.org/uc/item/0zw8f6gp.

[13] R. Marino, O., Subagiyo, H., \& Alamanda, "Masyarakat sipil mengawasi alam: Review izin Industri berbasis lahan,” Jakarta, 2013.

[14] Walhi, "Tinjauan Lingkungan Hidup 2018; Masa Depan Keadilan Ekologis di Tahun Politik,” 2018. Accessed: Sep. 14, 2021. [Online]. Available: https://www.walhi.or.id/wpcontent/uploads/2018/12/Layout_Tinjauan-Lingkungan-2018.pdf.

[15] V. Saeng, Herbert Marcuse: Perang Semesta Melawan Kapitalisme Global. Gramedia Pustaka Utama, 2012.

[16] J. D. . Sachs and A. M. Warner, "Natural Resource Abundance and Economic Growth," 1995. Accessed: Sep. 14, 2021. [Online]. Available: https://www.nber.org/system/files/working_papers/w5398/w5398.pdf.

[17] T. K. Lynn, The paradox of plenty : oil booms and petro-states. University of California Press, 1997.

[18] T. I. Palley, "Combating the Natural Resource Curse with Citizen Revenue Distribution Funds: Oil and the Case of Iraq," Foreign Policy Focus, pp. 1-12, 2003, Accessed: Sep. 14, 2021. [Online]. Available: www.fpif.org.

[19] M. Humphreys, J. D. Sachs, and J. E. Stiglitz, Escaping the Resource Curse. Columbia University Press, 2007.

[20] V. Shiva, Staying Alive: Women, Ecology and Survival in India, First Published. 1988.

[21] G. Hardin, "The tragedy of the commons: The population problem has no technical solution; it requires a fundamental extension in morality.," Science (80-. )., vol. 162, no. 3859, pp. 1243-1248, 1968, doi: 10.1126/SCIENCE.162.3859.1243.

[22] E. Endaryanta, Politik Air di Indonesia: Penjarahan Si Gedhang oleh Korporasi AquaDanone. 2007.

[23] W. R. Jati, "Manajemen Tata Kelola Sumber Daya Alam Berbasis Paradigma Ekologi Politik," Polit. J. Ilmu Polit., vol. 3, no. 2, pp. 98-111, May 2013, doi: 10.14710/POLITIKA.3.2.2012.98-111.

[24] U. Beck, Risk Society: Towards A New Modernity. 1992. 